\title{
Mapping of marine benthic invertebrates in the Osloforord and the Skagerrak: sampling data of museum collections from 1950-1955 and from recent investigations
}

\author{
Eivind Oug', Marit E. Christiansenn ${ }^{2}$ Kristine Dobbe², Ann-Helén Ranning' ${ }^{2}$ Torkild Bakken ${ }^{3}$ and Jon A. Kongsrud ${ }^{4}$
}

Oug E, Christiansen ME, Dobbe K, Rønning AH, Bakken T, Kongsrud JA. 2015. Mapping of marine benthic invertebrates in the Oslofjord and the Skagerrak: sampling data of museum collections from 1950-1955 and from recent investigations. Fauna norvegica 35: 35-45.

Data from large sampling programmes for the mapping of marine invertebrates in the Oslofjord, Norway, and the Skagerrak, spanning more than six decades, are compiled and digitized to provide easy access in modern data repositories. Two sampling programmes undertaken in the period 1950-55 are still the most extensive mapping of marine benthic fauna in the area. Information from a total of more than 900 localities, or sampling events, covering all benthic habitats in the Oslofjord and coastal waters to Kvitsøy in Rogaland county, have been carefully digitized from field notes, original sea charts, and primary observations from sample handling in the field. Geographical coordinates referred to WGS84 chart datum have been fixed with a general accuracy of $20 \mathrm{~m}$ in the Oslofjord and $100-250 \mathrm{~m}$ in coastal areas, based on precise map sketches with cross-bearings to land objects and chart annotations. Most samples were collected using triangular, Agassiz and lightweight dredges. The collected material has been deposited in the collections of the Natural History Museum, University of Oslo. Two recent projects, 'Polyskag' and 'Bioskag' (2006-2014), are briefly described. The projects focused on the diversity of marine bristle worms (Polychaeta), inter alia providing material for molecular genetic analyses. Type localities for early described species and generally understudied biotopes were visited. The data from the 1950s, together with recent studies, constitute a considerable resource for studies of biodiversity, facilitated through the sharing of species records from the museum collections in modern data repositories. The accurate positioning of sampling localities in the 1950s is of particular value for documenting species distributions over long time spans, thus providing a reference base for studying present and future species changes and assessing the effects of human influence and environmental changes in the Oslofjord and the Skagerrak.

doi: 10.5324/fn.v35i0.1944. Received: 2015-11-04. Accepted: 2015-12-17. Published online: 2015-12-21. ISSN: 1502-4873 (printed), 1891-5396 (electronic).

Keywords: benthic fauna, 1950-55, digitized sampling data, Oslofjord, Skagerrak

1. Norwegian Institute for Water Research, Region South, Jon Lilletuns vei 3, NO-4879 Grimstad, Norway

2. Natural History Museum, University of Oslo, PO Box 1172 Blindern, 0318 Oslo, Norway

3. Norwegian University of Science and Technology, NTNU University Museum, NO-7491 Trondheim, Norway

4. University Museum of Bergen, University of Bergen, PO Box 7800, NO-5020 Bergen, Norway

Corresponding author: Eivind Oug

E-mail: Eivind.oug@niva.no 


\section{INTRODUCTION}

The Oslofjord and the coastal waters of the Skagerrak were among the first areas to be explored for marine life by scientists in the eighteenth and nineteenth centuries. The small city of Drøbak in the Oslofjord, in particular, has been a centre for marine investigations, starting with Otto Friderich Müller, and has had an unbroken tradition since the establishment of the biological station in Drøbak in 1894 (Broch 1954). Despite its long historic tradition, the knowledge of the marine fauna in the area is still inadequate and incomplete. Knowledge of the fauna, and information from earlier investigations, is much needed today, both for environmental surveillance and monitoring in the area, which is heavily influenced by human activities, as well as for scientific studies of biodiversity, species distribution and marine ecosystems.

Most early investigations were carried out in the vicinity of Drøbak or in fjord areas along the coast (e.g. Müller 1777-1806; Ørsted 1845; Asbjörnsen 1853; Sars 1868; Kiær and Wollebæk 1913; Petersen 1915; Sømme 1927; Broch 1935). Then, in the period 1950-1955 an extensive and broad-based sampling of benthic invertebrates was carried out covering all areas and habitats in the Oslofjord and coastal waters on the south coast of Norway. The sampling was performed as part of a large-scale cooperation between Norwegian zoological museums in order to complete the museum collections at the time from areas of the Norwegian coast that had been insufficiently investigated (Soot-Ryen et al. 1966; Sneli 2010). The collected material was to be made available for revisions by specialists. It was further intended that the collections should form a core material for a series of publications on Nordic marine fauna named 'Marine Invertebrates of Scandinavia (MIOS)'. The first volume in the series appeared in 1966 (Millar 1966) and nine later volumes were issued (Christiansen 1969; Clark 1970; Salvini-Plawen 1975; Nilsson-Cantell 1978; Høeg and Lützen 1985; Holthe 1986; Pleijel 1993; Madsen and Hansen 1994; Sandberg and McLaughlin 1997), but the original idea of a series covering more than 40 systematic groups was never completed. From the Oslofjord and the Skagerrak more than 900 samples were taken altogether, the majority with the use of a triangular dredge or a lightweight dredge. The material is deposited in the collections at the Natural History Museum, University of Oslo (NHMO). Despite great efforts to work up the material and make it accessible to specialists, only part of it has been completed and published. Species dealt with in MIOS have mostly been reported with summary information and very rough geographic positioning of finds indicated on regional maps.

In a recent project ('Polyskag') aimed at mapping and describing the marine bristle worms (Polychaeta) in the Oslofjord and coastal waters of Skagerrak, a part study included compiling and making accessible species information from earlier samplings in museum collections. It soon became clear that the collections from the 1950s were of particular value because of the amount of material from a broad array of invertebrate groups and because all samples were well documented. A work was therefore initiated to digitalize all original information from the samplings. A priority task has been to locate original sampling localities and supply geographical coordinates in electronic format for all localities. This makes it possible to report detailed information about samples and materials in modern information retrieval systems, hence facilitating the present use of the data. Modern studies in coastal waters of Skagerrak mainly focus on species ecology and environmental issues with relation to management. The Polyskag project was intended to supplement the current main activities. The data from the 1950s, in particular, will form a reference for future studies of species changes and environmental assessments in the area.

In the open waters of the Skagerrak, a Swedish-Norwegian cooperative project ('Bioskag') studying benthic fauna and biodiversity has been carried out with sampling cruises in 2006 and 2009. The offshore and deep waters of the Skagerrak have been far less studied than the coastal waters and fjords, but the area was explored in rather comprehensive Swedish expeditions in the 1930s (Enequist 1949; Eliason 1962; Jägerskiöld 1971) and by German surveys in the 1970s (Hartmann-Schröder 1974). The Bioskag project was initiated to increase the knowledge of species composition and species distributions in the Skagerrak by extensive sampling using a variety of sampling gears. The Bioskag and Polyskag projects complement each other, providing data for both coastal and deep-water areas of the Skagerrak.

The present paper gives an overview of the collections made in 1950-55 with particular focus on the location of sampling stations, sampling methods, and bottom types that were covered. All digitalized sample information has been deposited in open access repositories. In addition, short accounts of sampling data from the Polyskag and Bioskag projects are given. In subsequent papers, species data from both the collections in 1950-55 and from the recent projects will be presented. Both Polyskag and Bioskag have been carried out under the framework of the Norwegian Taxonomy Initiative, which is a broadscale programme for mapping species diversity in Norway. Following up on the geo-referencing of sampling localities, species records will be supplied to the species mapping services in the Norwegian Biodiversity Information Centre and the Global Biodiversity Information Facility (GBIF).

\section{The study area}

The Skagerrak forms a branch of the North Sea situated between the south-east coast of Norway, the south-west coast of Sweden and the Jutland peninsula in Denmark (Figure 1). For management purposes it is usually delineated from the North Sea proper by drawing a borderline from the southernmost point on the Norwegian mainland (Lindesnes) to NW Jutland (Karlson et al. 2001). The mean depth is $210 \mathrm{~m}$ and the maximum depth about $700 \mathrm{~m}$. The Skagerrak, hence, is deeper than the North Sea proper. The maximum depth 
is located SE of Norway in a deep basin that forms a part of the Norwegian Trench, a deep channel running through the Skagerrak and turning northwards along the Norwegian west coast. Surface waters in the Skagerrak are circulating in an anticlockwise manner driven by the inflow of brackish water from the Baltic and surface waters from the southern North Sea entering north of Jutland. The salinity varies from 25 to 32 psu due to discharges of freshwater from Scandinavian and continental rivers. In deeper areas, high-saline water of Atlantic origin enters into the Skagerrak through the North Sea (Ståhl et al. 2004; Røed and Albretsen 2007). Through the Norwegian Trench, Skagerrak has a direct connection with the Norwegian Sea. Bottom sediments are mostly sandy in a wide and relatively

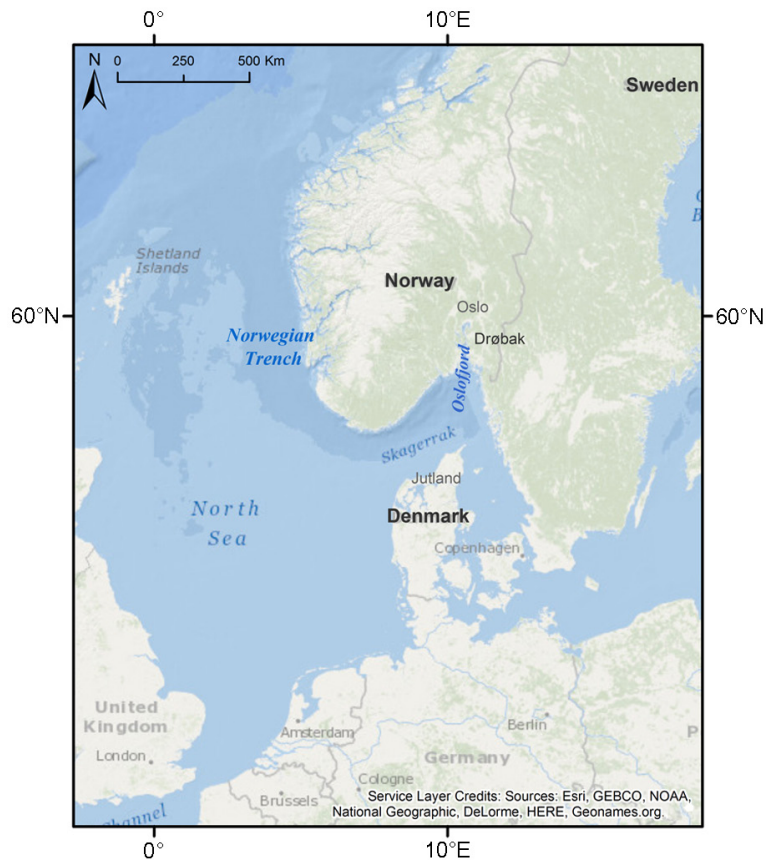

Figure I. Map indicating the study area in the Oslofjord and the Skagerrak shallow bank area north of Jutland, but turn into silt and clay in the deep Norwegian Trench and towards the Norwegian and Swedish coastal areas (Karlson et al. 2001; Ståhl et al. 2004). In inshore Norwegian waters the topography is very heterogeneous with a mosaic of bottom types.

The Oslofjord extends about $110 \mathrm{~km}$ northwards from the inner part of the Skagerrak. In the outer fjord there are several deep basins (200-400 m) separated by more shallow areas. The inner fjord is separated from the outer fjord by a narrow passage with a shallow sill $(19 \mathrm{~m})$ close to the city of Drøbak. The shallow sill severely limits the exchange of deep water in inner fjord basins (>150 m). The inner fjord with the city of Oslo was until a few decades ago severely polluted from municipal effluents and industrial waste. Due to strong efforts to reduce wastewater effluent discharges, i.e. with the construction of purification plants, the environmental status has improved in recent years (Dolven et al. 2013). The region around the Oslofjord is the most densely populated area in Norway with more than one million inhabitants. Currently there are strong initiatives to further reduce the impact of human activities and protect areas of particular value. During the last decades two marine national parks have been established in the outer Oslofjord and inner Skagerrak (Ytre Hvaler National Park, Færder National Park).

\section{Organization and sampling cruises 1950-1955}

The sampling in the Oslofjord and the Skagerrak was carried out as two separate but coordinated projects. Most samples from the Oslofjord were collected in 1951-55 in a project organized from the Biological Station in Drøbak, University of Oslo, and managed by professor and director Bjørn Føyn. Marit E. Christiansen (second author of the present paper) and Bengt O. Christiansen were contracted to carry out the sampling and sample sorting. Altogether 637 samples were taken during the course of 158 day cruises. Sampling was carried out on a year-round basis, but a larger part of the samples were taken during the summer period (April-September). The samples

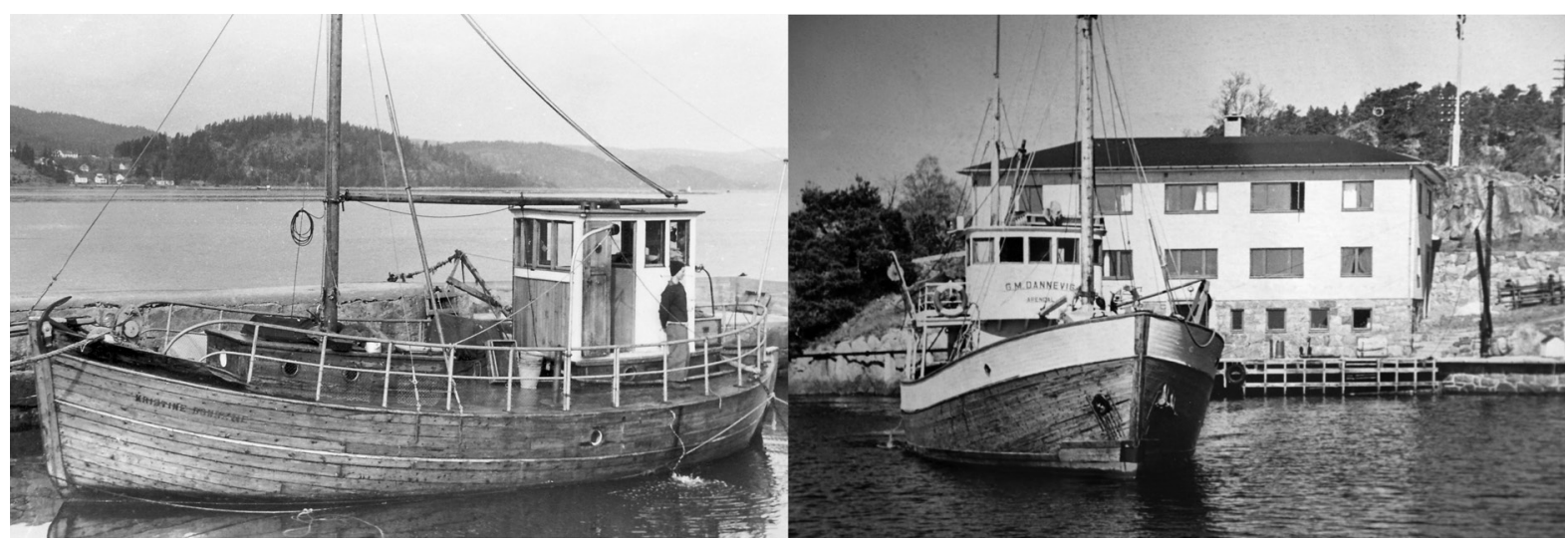

Figure 2. Research vessels used during the sampling. Left: R/V Kristine Bonnevie, belonging to the Biological Station in Drøbak. Right: R/V G.M. Dannevig in front of the Flødevigen Marine Research Station, Arendal. Photo: Bengt O. Christiansen (left) and Institute of Marine Research (Havforskningsinstituttet) (right). 
were collected using the research vessel R/V Kristine Bonnevie, belonging to the Biological Station (Figure 2) and a small open boat (Moses). The samples will in the following be referred to as the 'Drøbak-collections'.

The samples from the coastal areas of the Skagerrak, including outer Oslofjord, were collected in 1950-53 in a project organized by the Natural History Museum in Oslo and managed by curator Nils Knaben. The research vessel R/V G.M. Dannevig, belonging to the Flødevigen Marine Research Station in Arendal, was hired for the sampling (Figure 2), which was carried out as summer cruises along the coast, one cruise each year. Altogether 280 samples were taken during a total of 46 cruise days. The sampling was carried out by curator Knaben, the museum assistant Kari Krog and students of biology. The samples will in the following be referred to as the 'Dannevig-collections'.

\section{Sampling stations 1950-1955}

The Drøbak-collections covered most parts of the Oslofjord from the mouth south of the lighthouse Færder to the head at the city of Oslo (Figure 3). Roughly 200 samples were taken from the inner part of the fjord inside the sill at Drøbak, 240 samples from the narrow sound and wide central part of the fjord south of Drøbak, and 200 samples from the outer and most open part of the fjord. The most intensively sampled areas were the region close to Drøbak, including the fjord sill and the narrow side branch Hallangspollen (Figure 3). The majority of the samples

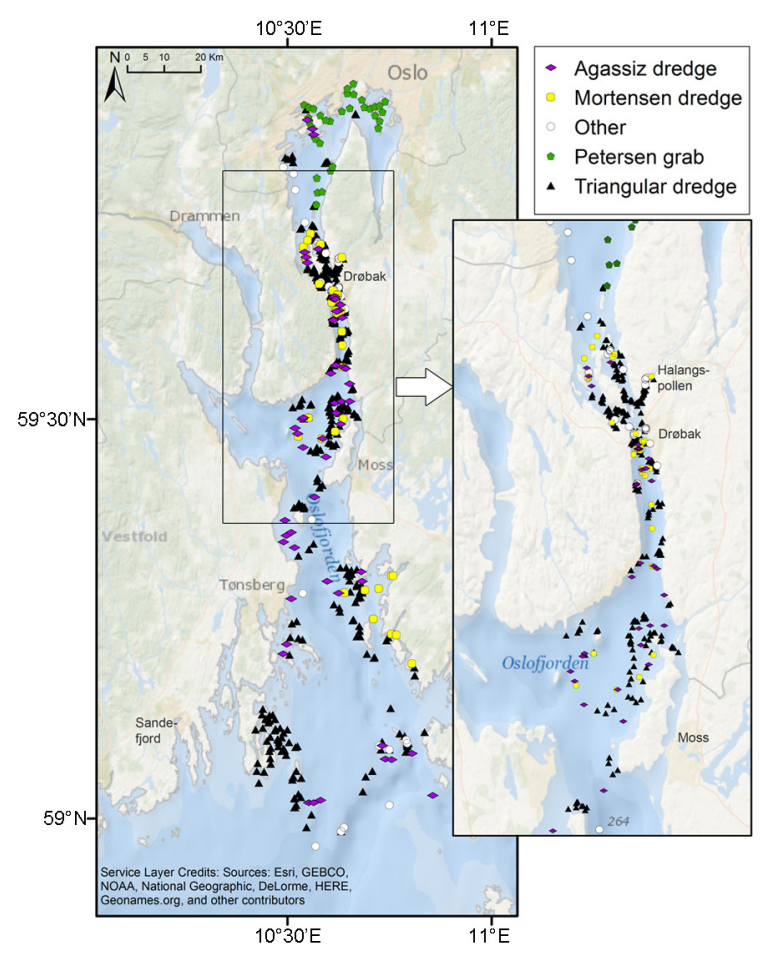

Figure 3. The Oslofjord with sampling stations from the Drøbakcollections (1951-55). The expanded area illustrates the most intensively sampled area in the central fjord close to Drøbak.

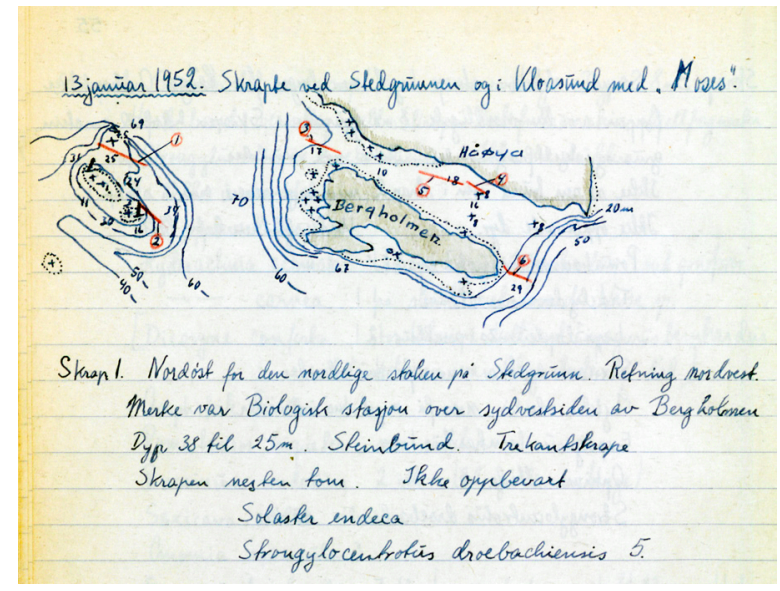

Figure 4. Sketch from triangular dredge sampling near Drøbak, Oslofjord, 13 January 1952. Red lines indicate the tracks of dredge hauls (samples 1-6). Land objects are shaded, underwater rocks $(+)$ and depth contours are shown for precise location of samples. From the field journal of the Drøbak-collections, Marit and Bengt O. Christiansen.

were collected from rather shallow $(<20 \mathrm{~m})$ to moderate depths $(20-100 \mathrm{~m})$. In the central and outer parts of the fjord several deep areas (> $200 \mathrm{~m}$ ) were also sampled. All samples were documented in a field journal giving positions, depths, and collected bottom material. Several positions were shown by detailed map sketches and cross-bearings on landmarks, making exact re-location of station positions possible (see example in Figure 4).

A complete list of stations with geographical coordinates are deposited in an open access repository at the Global Biodiversity Information Facility (GBIF) portal (Drobak-collections doi: $10.15468 / \mathrm{mg} 712 \mathrm{t}$ ), and a scanned version of the field journal is deposited at the DUO Research Archive, University of Oslo (http://urn.nb.no/URN:NBN:no-52236) (Table 1).

The Dannevig-collections covered Norwegian coastal areas from the mouth of the Oslofjord to Kvitsøy on the west coast (Figure 5). In addition, about 20 samples were taken offshore from deeper areas. The most densely covered area was the part of the coast from about the city of Arendal to the headland Lista. Most samples were taken from shallow and moderate depths $(10-100 \mathrm{~m})$. The deepest samples were from more than $400 \mathrm{~m}$ depth in open waters of the Skagerrak. Sampling stations were documented by pencil markings in sea charts. Data for each station including local place names, depths, towing times (dredge samples) and bottom material were taken down on separate sheets. Geographical coordinates based on chart datum of the time were recorded for about one-third of the sampling stations.

A complete list of stations with geographical coordinates are deposited in an open access repository at the Global Biodiversity Information Facility (GBIF) portal (Dannevig collections doi: $10.15468 / \mathrm{hwvr} 0 \mathrm{~m}$ ), and scanned sheets with information on 


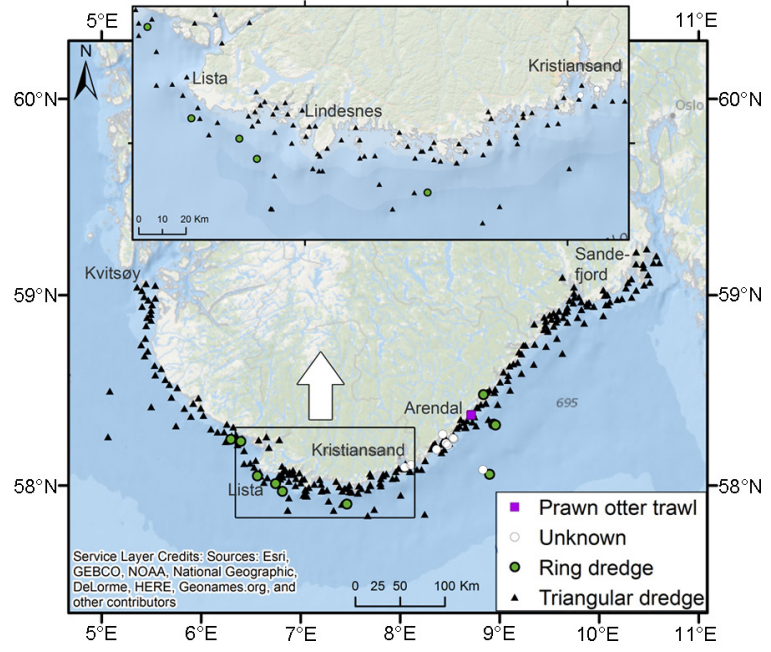

Figure 5. The south coast of Norway with sampling stations from the Dannevig-collections (1950-53). The expanded area from Lista to Kristiansand illustrates the sampling design covering fjords, archipelagos and open sea areas.

sampling is deposited at the DUO Research Archive, University of Oslo (http://urn.nb.no/URN:NBN:no-52235) (Table 1).

\section{Sampling and sample treatment 1950-1955}

In the Oslofjord, the samples (Drøbak-collections) were taken from a variety of bottom types ranging from rock and boulders to soft substrates. All depths from the intertidal to the deep fjord basins were covered. Table 2 gives a summary of the sampling according to bottom types, depths and type of gear used. Major bottom types, such as rock and coarse sediments, muddy sediments and mixed substrates with stones, mud, and shell fragments, were all well represented. There were also several samples from deposits of calcareous material (dead shells, the bristle worm Pomatoceros, algae) and from substrates with living algae, seagrass (Zostera) and living corals (Lophelia). Most bottom types, except algae, seagrass and corals, were sampled over a wide range of depths.

The majority of the samples were taken with a standard- type triangular dredge. In some case a heavy rectangular dredge (firm frame, about $80 \mathrm{~cm}$ width) or an Agassiz dredge equipped with a tickler-chain were used. Several samples were also taken with a $35 \mathrm{~cm}$ wide lightweight rectangular dredge (Mortensen dredge), specifically designed for collecting small surface-living organisms in soft sediments (Mortensen 1925). Other gears used on soft bottoms were a $0.116 \mathrm{~m}^{2}$ Petersen grab and a prawn otter trawl. Occasionally, a simple hand-operated corer was also used, especially for collecting foraminiferans (B.O. Christiansen 1958). Details for depths, gear, and bottom material are entered in the list with station coordinates (for reference to online repository see Table 1).

All samples from the Oslofjord (Drøbak-collections) with sediments were washed on wooden-framed netting sieves with a mesh size of 1-2 mm. In most cases one bucket of collected bottom material was worked up, but occasionally larger amounts of material were processed. The sieving was variously performed onboard the research vessel R/V Kristine Bonnevie, in wet rooms at the Biological Station, or onshore when the samples were taken from a small vessel (Figure 6). All visible organisms were hand-picked and immediately fixed in $70 \%$ ethanol. Alcohol was preferred to ensure best possible

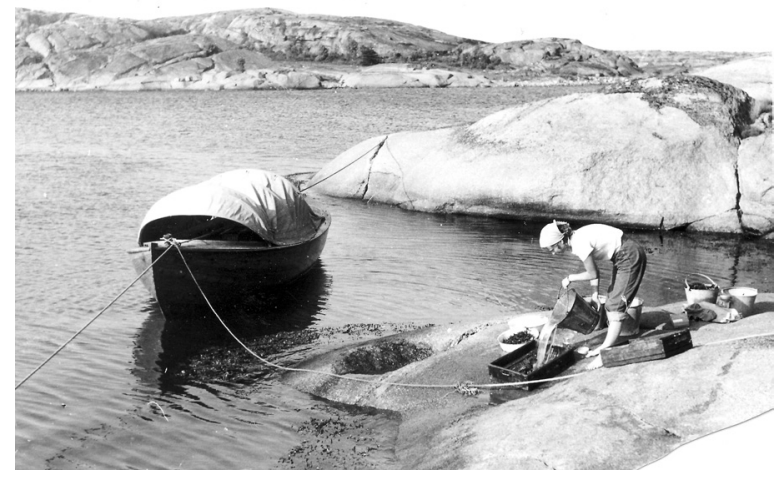

Figure 6. Marit E. Christiansen is sieving a triangular dredge sample collected close to the shore. The small boat Moses, used for sampling, in the background. From Vasser, outer Oslofjord. Photo: Bengt O. Christiansen.

Table I. References to open online repositories where data are stored, with dataset names and permanent links to repositories.

\begin{tabular}{|c|c|c|}
\hline Repository & Dataset name & Reference DOI \\
\hline Global Biodiversity Information Facility (GBIF) & Drobak-collections & doi: $10.15468 / \mathrm{mg} 712 \mathrm{t}$ \\
\hline Global Biodiversity Information Facility (GBIF) & Dannevig collections & doi: $10.15468 /$ hwvr0m \\
\hline Global Biodiversity Information Facility (GBIF) & POLYSKAG-collections & doi: 10.15468/zfcaa5 \\
\hline Global Biodiversity Information Facility (GBIF) & BIOSKAG-collections & doi: 10.15468/mpifue \\
\hline Global Biodiversity Information Facility (GBIF) & $\begin{array}{l}\text { Dannevig- and Drobak-collections } \\
\text { Polychaeta }\end{array}$ & doi: $10.15468 / y 6 c c t p$ \\
\hline DUO Research Archive, University of Oslo & Drøbak-collections log 1951-1955 & http://urn.nb.no/URN:NBN:no-52236 \\
\hline DUO Research Archive, University of Oslo & $\begin{array}{l}\text { Dannevig-collections sampling stations } \\
\text { 1950-1953 }\end{array}$ & http://urn.nb.no/URN:NBN:no-52235 \\
\hline
\end{tabular}


preservation for shell-bearing organisms. Larger and easily identified species were generally discarded, but species and numbers of specimens were registered in the field journal.

The samples from the south coast of Norway (the Dannevigcollections) covered a depth range from 3 to more than $600 \mathrm{~m}$. Most samples from the coastal waters were taken at shallow to moderate depths, whereas more than 20 samples were taken deeper than $400 \mathrm{~m}$ off the coast. The samples included a wide range of substrates (Table 3). Most samples were taken from sandy and sand-mixed substrates with pebbles and gravel and often with shell sand or shell fragments. Samples from hard bottoms with or without algae were mostly taken from shallow and moderate depths $(<60 \mathrm{~m})$, whereas samples from soft mud were mostly from deeper areas $(>100 \mathrm{~m})$. In several cases

Table 2. Summary of bottom types, depths and sampling gear for the Drøbak-collections. Corresponding habitat classes from the EUNIS habitat classification system (EEA 2015) are shown for the bottom types. Sampling gears: TD = triangular dredge, RD = rectangular dredge, $\mathrm{MD}=$ Mortensen dredge, $\mathrm{AGZ}=$ Agassiz dredge, $\mathrm{PG}=$ Petersen grab, POT = prawn otter trawl. Samples lacking information on substrate material components are not included.

\begin{tabular}{|c|c|c|c|c|c|}
\hline Seabed type & Substrate material components & $\begin{array}{l}\text { EUNIS habitat } \\
\text { class codes }\end{array}$ & $\begin{array}{l}\text { No. of } \\
\text { samples }\end{array}$ & Depth (m) & Gear \\
\hline Hard bottom & Rock, boulder, cobbles, pebbles & A4.1, A4.2, A4.3 & 87 & $10-120$ & TD, RD, AGZ \\
\hline \multirow{4}{*}{ Sediments } & $\begin{array}{l}\text { Pebbles with gravel or sand; +/- shell } \\
\text { fragments, slag crusts }\end{array}$ & A5.13, A5.14 & 83 & $8-85$ & TD, MD, AGZ \\
\hline & $\begin{array}{l}\text { Sand and sand-mixed mud; +/- shell } \\
\text { sand }\end{array}$ & $\begin{array}{l}\text { A } 5.23, \text { A } 5.24 \\
\text { A5.26 }\end{array}$ & 22 & $3-100$ & TD, RD, AGZ \\
\hline & Mud & A5.34, A5.36 & 137 & $0.5-230$ & TD, RD, AGZ, PG, POT \\
\hline & Mud with $\mathrm{H}_{2} \mathrm{~S}$ & A5.72 & 19 & $6-85$ & TD, MD, AGZ, PG \\
\hline \multirow{2}{*}{$\begin{array}{l}\text { Mixed } \\
\text { sediments } \\
\text { (poorly sorted) }\end{array}$} & $\begin{array}{l}\text { Pebbles/gravel with mud; +/- dead } \\
\text { shells or corals, slag crusts }\end{array}$ & $\begin{array}{l}\text { A } 5.43, \text { A } 5.44, \\
\text { A5.45 }\end{array}$ & 101 & $7-205$ & TD, RD, MD, AGZ, PG \\
\hline & $\begin{array}{l}\text { Pebbles/gravel/mud with (mostly } \\
\text { detached) seaweeds }\end{array}$ & A5.52 (in part) & 54 & $10-70$ & TD, AGZ \\
\hline $\begin{array}{l}\text { Calcareous } \\
\text { deposits }\end{array}$ & $\begin{array}{l}\text { Dead shells, calcareous algae, } \\
\text { calcareous worms, dead corals }\end{array}$ & A5.14 (in part) & 33 & $5-110$ & TD, AGZ \\
\hline \multirow{3}{*}{ Biotic habitats } & $\begin{array}{l}\text { Algae (red, green, kelp); +/- boulder, } \\
\text { pebbles }\end{array}$ & A 3.21, A3.22 & 48 & $2-25$ & $\mathrm{TD}$ \\
\hline & Seagrass (Zostera) & A5.53 & 6 & $2-16$ & TD \\
\hline & Living corals & A5.63 & 10 & $70-140$ & TD \\
\hline
\end{tabular}

Table 3. Summary of bottom types, depths and sampling gear for the Dannevig-collection on the south coast of Norway. Corresponding habitat classes from the EUNIS habitat classification system (EEA 2015) are shown for the bottom types. Sampling gears: TD = triangular dredge, RID = ring dredge, POT = prawn otter trawl. Samples lacking information on substrate material components are not included.

\begin{tabular}{|c|c|c|c|c|c|}
\hline Seabed type & Substrate material components & $\begin{array}{l}\text { EUNIS habitat } \\
\text { class codes }\end{array}$ & $\begin{array}{l}\text { No. of } \\
\text { samples }\end{array}$ & Depth, m & Gear \\
\hline Hard bottom & Rock, boulder, cobbles and pebbles & $\mathrm{A} 4.1, \mathrm{~A} 4.2, \mathrm{~A} 4.3$ & 39 & $5-120$ & $\mathrm{TD}$ \\
\hline \multirow{4}{*}{ Sediments } & $\begin{array}{l}\text { Pebbles, gravel; sand, +/- shell fragments, } \\
\text { slag crusts }\end{array}$ & A5.13, A5.14 & 32 & $6-185$ & TD, RID \\
\hline & Sand and sand-mixed mud; shell sand & $\begin{array}{l}\text { A } 5.23, \text { A } 5.24 \\
\text { A5.26 }\end{array}$ & 75 & $3-420$ & TD, RID \\
\hline & Mud & A5.34, A5.36 & 44 & $6-470$ & TD, RID, POT \\
\hline & Mud with $\mathrm{H}_{2} \mathrm{~S}$ & A5.72 & 2 & $78-90$ & $\mathrm{TD}$ \\
\hline \multirow{2}{*}{$\begin{array}{l}\text { Mixed sediments } \\
\text { (poorly sorted) }\end{array}$} & $\begin{array}{l}\text { Pebbles/gravel and mud; +/- dead shells, } \\
\text { slag crusts }\end{array}$ & $\begin{array}{l}\text { A } 5.43, \text { A } 5.44, \\
\text { A5.45 }\end{array}$ & 24 & $4-235$ & TD, RID \\
\hline & $\begin{array}{l}\text { Pebbles/gravel/mud with (mostly detached) } \\
\text { seaweeds }\end{array}$ & A5.52 (in part) & 30 & $12-85$ & $\mathrm{TD}$ \\
\hline $\begin{array}{l}\text { Calcareous } \\
\text { deposits }\end{array}$ & Dead shells, shell sand, calcareous algae & A5.14 (in part) & 1 & 12 & $\mathrm{TD}$ \\
\hline Biotic habitats & $\begin{array}{l}\text { Algae (red, green, kelp); +/- boulder, } \\
\text { pebbles }\end{array}$ & A3.21, A3.22 & 16 & $6-30$ & $\mathrm{TD}$ \\
\hline
\end{tabular}


detached kelp or kelp fragments were noted in the samples.

The majority of samples were taken with a triangular dredge (258 samples). Generally, the dredge was towed along upward-sloping seabed surfaces to collect from a range of depths. In a few cases a ring dredge (10 samples) or a prawn otter trawl (2 samples) was used. Collected material was washed on wooden-framed netting sieves (mesh size presumably 1-2 $\mathrm{mm}$ ). All visible organisms were hand-picked and immediately fixed in $4 \%$ formaldehyde-seawater solution. After the cruise all material was transferred to $80 \%$ ethanol for preservation. In some of the deep samples ( $>350 \mathrm{~m}$ ), most material had been washed out, and the three deepest samples from the Norwegian Trench $(530-660 \mathrm{~m})$ were all without material. Details for depths, gear, towing time (sledge samples) and collected material are entered in the list with station coordinates (for address to online repository see Table 1).

\section{Curation and identification}

All collected material, except for specimens that were not kept from the Drøbak-collections, has been included in the collections of the Natural History Museum, University of Oslo (NHMO). The material has been sorted into major groups, initially to phylum or class level, but in several cases further to family level. The major groups represented include sponges (Porifera), hydroids and sea anemones (Hydrozoa, Anthozoa), bristle worms (Polychaeta), bivalves and snails (Mollusca), crustaceans (Crustacea), echinoderms (Echinodermata), bryozoans (Bryozoa) and tunicates (Ascidiacea). The material is kept in $80 \%$ ethanol (wet material) or dry (several Mollusca) in temperature-regulated storage magazines.

Several species and species groups have been examined by specialists in studies of species occurrence and distribution. Table 4 shows a list of faunal publications that have made use of the material. Further, selected species groups have been taxonomically studied by graduate students. All identified species have been transferred to separate glass tubes or small vials, one tube for each species in each sample, and stored in collective jars for each species. Larger specimens are kept in separate jars. Identified material has generally been supplied with museum access numbers and catalogued (presently more than 5500 catalogue numbers: A.H. Rønning, pers. obs). It appears, however, that parts of the identified material have neither been catalogued nor published. Presently, no overview of non-catalogued material exists.

Larger and easily identified species that were not kept in the Drøbak-collections were listed for each sample in the field journal (for address to online repository of field journal see Table 1). Molluscs and echinoderms were most often recorded, but some hydroids, soft corals, polychaetes, crustaceans, brachiopods and ascidians were also noted.

\section{Geo-referencing of sampling stations $1950-55$}

The stations in the Drøbak and Dannevig-collections were originally recorded in different ways. In the Drøbak-collections stations were positioned by local place names, depth and usually also detailed map sketches and cross-bearings on landmarks. The information is found in the field journal where map sketches were also drawn (Figure 4). In most cases it was possible to re-locate the stations with high precision $(20 \mathrm{~m})$ from presently used official digital sea maps (map service from The Norwegian Coastal Administration, kystverket.no). In cases of stations in open areas with some distance from easily located land objects, the precision is somewhat lower, about $100 \mathrm{~m}$. Local place names that turned out to be difficult to ascertain from maps have been confirmed by the second author (M.E. Christiansen).

The stations from the Dannevig-collections were originally positioned by pencil markings in original sea charts. Further information including local place names, bearings to land objects, depths and also for several geographical coordinates, is found in the cruise log and in separate sheets for each sampling station. All stations were allocated to predefined

Table 4. Faunal publications including material collected from the samplings in 1950-1955.

\begin{tabular}{lll}
\hline Phylum & Class/group & Author \\
\hline Cnidaria & Hydrozoa & Christiansen BO (1972) \\
Annelida & Polychaeta & Loshamn (1981); Winsnes (1981); Holthe (1986); Pleijel (1993) \\
Mollusca & Prosobranchia & Sneli (1975) \\
& Caudofoveata & Salvini-Plawen (1975) \\
Crustacea & Cirrepedia & Nilsson-Cantell (1978); Høeg and Lützen (1985) \\
& Isopoda & Pethon (1970) \\
& Decapoda & Christiansen ME (1969, 1972); Sandberg and McLaughlin (1997); Ingle and Christiansen ME \\
& Crinoidea & Clark (1970) \\
Echinodermata & Holothuroidea & Madsen and Hansen (1994) \\
& (all) & Brun (1964) \\
& Ascidiacea & Millar (1966) \\
\hline
\end{tabular}


coastal stretches delineated by the major coastal lighthouses. It was possible to re-locate nearly all stations with a precision of 100-250 m from currently used official digital sea maps (kystverket.no) using original map markings, depths and local place names as the most reliable information. For some offshore dredge stations where bearings on landmarks and depths did not correspond with currently used digital sea maps, the location is less precise, from 500 to $800 \mathrm{~m}$, and for one station, probably erroneous, $1.4 \mathrm{~km}$. Station coordinates, when recorded, were of less use because the precision was low and the chart datum was not stated. Most probably the coordinates were based on a previously used Norwegian chart datum. Attempts to compensate for general differences between the old chart datum and currently used digital maps did not improve the positioning sufficiently and was generally considered unsuccessful.

The presently recorded coordinates (in both decimal-degrees and decimal-minutes format) were all based on WGS84 chart datum and extracted from official digital maps (Kystverket. no). The precision for each station was also determined and was recorded along with the sample information. For dredge samples in the Drøbak-collections that were shown on map sketches, the coordinates for the starting point of the hauls were recorded. Direction and length of the hauls are shown on the map sketches.

\section{Sampling from the Polyskag and Bioskag projects}

During the Polyskag project (2010-14) more than 50 samples were taken from the intertidal and shallow subtidal to depths exceeding $200 \mathrm{~m}$ in the Oslofjord and in the coastal waters of the Skagerrak (Figure 7). The samples were collected using hand-operated gear, hand-picking by divers, and by use of grabs, dredges and epibenthic sledges. Habitats that generally have been little investigated were included as far as possible. In addition, type localities of early described polychaete species from the Drøbak area and outer Oslofjord were visited in order to obtain new material for critical taxonomic work. About 30 polychaete species were originally described from the area, most of them by Otto Friderich Müller, Michael Sars and Anders Ørsted in the eighteenth and nineteenth centuries. Original material for several of the species is deposited in the collections at NHMO (Oug et al. 2014). Some few samples from the Drøbak-area were also taken close to $(<100 \mathrm{~m})$ sampling stations from the Drøbak-collections. A major part of the collected specimens was fixed in $96 \%$ ethanol, providing material for molecular genetic studies, but several samples were split into two parts, which were fixed in ethanol and formaldehyde solution, respectively. The material from the Polyskag project has been deposited in the collections at the University Museum of Bergen, University of Bergen.

During the Bioskag project (2006-09) about 180 samples were taken at two cruises (Bioskag I 2006, Bioskag II 2009), mainly in offshore Skagerrak waters (Figure 7). The BioskagII was also part of the Swedish inventory of marine benthic invertebrates (Karlsson et al. 2014) and some samples were

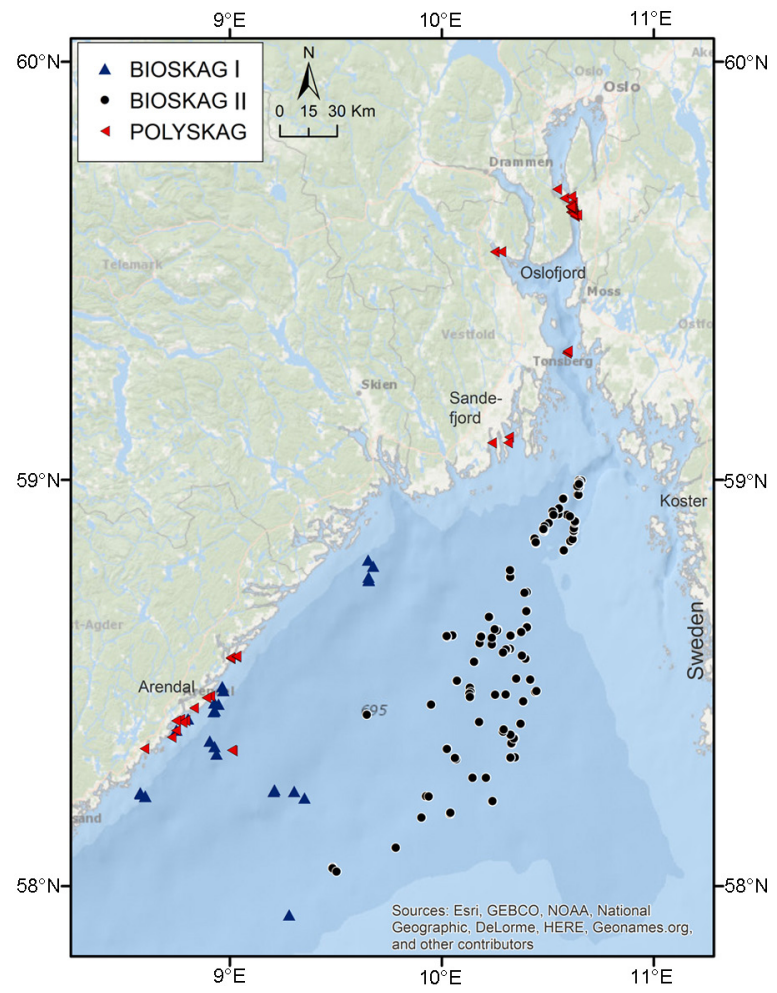

Figure 7. Sampling stations of the Polyskag and Bioskag projects.

taken within the Swedish and Danish Economical Zones. The sampling covered a depth range from 20 to $700 \mathrm{~m}$, with most samples from 150 to $500 \mathrm{~m}$ depth. An Agassiz trawl and various dredges and epibenthic sledges were used. Most samples were collected from soft bottom or mixed-sediment habitats, but some samples, actually also some rather deep samples (200-300 $\mathrm{m})$, were collected from hard-bottom habitats. The major part of the material, including bulk samples with sediments, was fixed in $96 \%$ ethanol. The remaining samples were fixed in formaldehyde solution. The material is deposited at the University Museum of Bergen, University of Bergen and the Natural History Museum in Gothenburg, Sweden (Karlsson et al. 2014).

Lists of sampling stations from the projects, with station coordinates, depths, gear used, towing time (sledge samples) and collected material are deposited in an open access repository at the Global Biodiversity Information Facility (GBIF) portal (Polyskag-collections doi: 10.15468/zfcaa5) (Bioskag-collections doi: 10.15468/mpifue) (Table 1).

\section{Sample metadata and transfer of faunal data to species mapping services}

All metadata are digitalized and presented open access in a data repository at the Global Biodiversity Information Facility (GBIF). There are separate datasets for the Drøbakand Dannevig-collections and for the projects Polyskag and Bioskag (Table 1). Information of samples follows the Darwin 
Core-format. The positions of sampling localities are given according to WGS84 in decimal-degree (mandatory for Darwin Core) and decimal-minute format (optional), with indicated precision (Drøbak- and Dannevig-collections) and annotations. Information for gear, depth, bottom type etc. is assembled from the field journal (Drøbak) and field notes (Dannevig).

The field journal from the Drøbak-collections and the sheets with sampling information from the Dannevig-collections are scanned in pdf format and deposited in an online open access repository at the University of Oslo (Table 1). All information in the field journal and sampling sheets is in Norwegian.

Work on supplying species records to the mapping services in the Norwegian Biodiversity Information Centre and GBIF is in progress. The first data to be supplied are for several families of polychaetes (about 20 families) (see Table 1 for reference to dataset Dannevig- and Drobak-collections Polychaeta). Detailed information on selected polychaete families that have been examined during the Polyskag and Bioskag projects will be published in a series of forthcoming papers.

The faunal information from the Drøbak- and Dannevig collections is presently in the form of species records. It is an objective for further work to continue the registration of noncatalogued material and to assemble complete species lists for each sample, whereupon the dataset Dannevig- and Drobakcollections Polychaeta deposited at GBIF (Table 1) will be updated. Digitalization of the field journal lists of species that was not kept in Drøbak-collections is in progress.

\section{DISCUSSION}

The Drøbak- and Dannevig-collections in 1950-1955 comprise the most extensive mapping of marine benthic fauna in the Oslofjord and coastal waters of the Skagerrak. The value of the material is very high for several reasons: the large number of samples, the large amount of collected material, the purposive treatment and curation, and the precise documentation of the sampling. The positions of sampling stations were originally indicated very accurately in order to ensure exact re-location of sites of species of particular interest or for collecting additional material. Today, the accurate localization is of high value for documenting species distributions in the 1950s, thus providing a reference base for present and future studies of species changes and the composition of species communities. The Oslofjord, in particular, has been strongly influenced by pollution and human activities, with maximal impact during the 1970-80s, when efforts to clean effluent discharges were implemented (Rosenberg et al. 1987; Dolven et al. 2013). All data that can be used to document the environmental status in earlier periods will be invaluable for present environmental assessments and for efforts to keep the fjord healthy with high biodiversity and a variety of species assemblages.

The work presented here by the digitalization of coordinates and additional information from the Drøbak- and
Dannevig-collections is in several ways parallel to an initiative undertaken in Sweden. A four-year project in Swedish coastal and offshore waters was designed to obtain new samples from both previously established sampling stations and new areas (Karlsson et al. 2014). Earlier sampling stations were mainly taken from the large inventory carried out in the 1920-30s (Jägerskiöld 1971) and digitized based on information from field journals, original sea charts and modern electronic sea charts (Karlsson et al. 2014) in largely similar ways to the present work. In addition, new areas were sampled in both the Kattegat and the Skagerrak (Karlsson et al. 2014). The recent projects, Polyskag and Bioskag, have both collaborated with the Swedish marine inventory programme to gain synergies so that most of the Skagerrak has been covered.

In the Swedish inventory more than 1200 benthic invertebrate species were recoded from 527 samples (Karlsson et al. 2014). Thirty species were new to science. The inventory demonstrated that significant new information was obtained, although the area is among the most studied marine areas in the world (e.g. Høisæter et al. 2011), in addition to the new information on species distribution that is essential to studies of species changes and environmental status. The number of species collected in the present studies is not yet known, as several species groups from the Drøbak- and Dannevigcollections have not been completed. However, the published faunal reports for groups that have been examined (Table 4) and results for polychaete families presently under study (Kongsrud, Bakken, Oug, unpublished), indicate that the total number of species will be high. A high number of species enhances the value of the Drøbak- and Dannevig-collections, particularly taking into account the precise geo-referencing of the sampling stations making it possible to reproduce species distributions exactly.

Most present-day benthic studies in Norwegian coastal waters of the Skagerrak are aimed at assessing environmental status or monitoring long-term changes, largely as a need to evaluate the influences of human activities. The preferred studies are using semi-quantitative or quantitative sampling methods to ensure comparability among investigations and allow for the use of classification systems to assess environmental status, as for instance the EU Water Framework Directive. Typically, the studies are restricted to a few suited biotopes, such as shallow hard bottoms (Norderhaug et al. 2015) and subtidal soft muddy sediments (Josefson et al. 2009). The studies incorporate detailed analyses of small-sized species $(1 \mathrm{~mm})$, hence providing information on faunal components that were partly lost in earlier investigations. However, these studies do not procure broadscale faunal data because of the limitations of habitats and sampling methods. Revisiting sampling stations from the comprehensive collections in the 1950s provides alternative methods for environmental assessments by comparing present and earlier distribution of species from different habitats. Essentially, this approach will cover a far longer time span than the contemporary monitoring studies (i.e. two decades, 
see Norderhaug et al. 2015). In the Oslofjord and coastal waters of the Skagerrak, environmental changes over eight to ten decades and more have been investigated from time series on shallow-water fish fauna (Fromentin et al. 1997; Johannessen et al. 2012), repeated sampling of Petersen's (1915) early softbottom studies (Rosenberg et al. 1987) and reconstruction of past foraminiferal species assemblages (Dolven et al. 2013). The collections of benthic fauna from the 1950s may supplement these studies by providing data for numerous species and a number of habitats that are not included in the presently examined historic data sets.

\section{ACKNOWLEDGEMENTS}

The sampling and the employment of Marit E. Christiansen and Bengt O. Christiansen (1951-55) were funded by the former Norwegian Council for Science and the Humanities. The georeferencing and digitalization of sampling stations were funded by GBIF Norway (to Kristine Dobbe). We are indebted to the late Professor Christoffer Schander, University of Bergen, for organizing the Bioskag project. We thank Petter Baardsen, Institute of Marine Research, for locating the ship's logbooks from R/V GM Dannevig, and Jon-Arne Sneli, Norwegian University of Science and Technology, for information on sampling gear. Katrine Kongshavn, University Museum of Bergen, assisted in preparing maps, and Christian Svindseth GBIF Norway helped with the GBIF repository. This study was in part funded by the Norwegian Taxonomy Initiative through the Norwegian Biodiversity Information Centre for the project 'Polyskag: Polychaetes in coastal areas of the Skagerrak - from early natural history to current needs of knowledge' (project number 70184216).

\section{REFERENCES}

Asbjörnsen PC. 1853. Bidrag til Christianiafjordens Litoralfauna. I. Mollusker. Nyt Magazin for Naturvidenskaberne 7: 307-366.

Broch H. 1935. Dei Bedeutung der Drøbak-Schwelle für die Bodenfauna der Garnelen-Felder. Det Norske VidenskapsAkademi, matematisk-naturvidenskapelig Klasse 1935. 32 pp.

Broch H. 1954. Zoologiens historie i Norge til annen verdenskrig. Akademisk Forlag, Oslo. 156 pp.

Brun E. 1964. Zoologiske bestemmelsestabeller Echinodermata. Universitetsforlaget, Oslo. $52 \mathrm{pp}$.

Christiansen BO. 1958. The foraminiferal fauna in the Drøbak Sound in the Oslo Fjord (Norway). Nytt Magasin for Zoologi 6: 5-91.

Christiansen BO. 1972. The hydroid fauna of the Oslofjord in Norway. Norwegian Journal of Zoology 20: 279-310.

Christiansen ME. 1969. Decapoda Brachyura. Marine Invertebrates of Scandinavia 2: 1-143.

Christiansen ME. 1972. Bestemmelsestabell over Crustacea Decapoda Tifotkreps. Universitetsforlaget, Oslo. 71 pp.

Clark AM. 1970. Crinoidea. Marine Invertebrates of Scandinavia 3: $1-55$.
Dolven JK, Alve E, Rygg B, Magnusson J. 2013. Defining past ecological status and in situ reference conditions using benthic foraminifera: a case study from the Oslofjord, Norway. Ecological Indicators 29: 219-233. doi:10.1016/j.ecolind.2012.12.031

EEA 2015. EUNIS habitat classification. European Environmental Agency. Internet: www.eea.europa.eu/themes/biodiversity/eunis Eliason A. 1962. Die Polychaeten der Skagerak-Expedition 1933. Zoologiske Bidrag Uppsala 33: 207-293.

Enequist P. 1949. Studies on the soft-bottom amphipods of the Skagerak. Zoologiske Bidrag Uppsala 28: 297-493.

Fromentin JM, Stenseth NC, Gjøsæter J, Bjørnstad ON, Falck W, Johannessen T. 1997. Spatial patterns of the temporal dynamics of three gadoid species along the Norwegian Skagerrak coast. Marine Ecology Progress Series 155: 209-222.

Hartmann-Schröder G. 1974. Polychaeten von Expeditionen der 'Anton Dohrn' in Nordesee und Skagerrak. Veröff Institut für Meeresforschung Bremerhaven 14: 169-274.

Høeg J, Lützen J. 1985. Crustacea Rhizocephala. Marine Invertebrates of Scandinavia 6: 1-90.

Høisæter T, Sneli JA, Schander C, Rapp HT, Berggren M. 2011. Xandarovula patula (Gastropoda: Ovulidae) new to Scandinavia. Marine Biodiversity Records 2011(4): e58.

Holthe T. 1986. Polychaeta Terebellomorpha. Marine Invertebrates of Scandinavia 7: 1-194.

Ingle RW, Christiansen ME. 2004. Lobsters, mud shrimps and anomuran crabs. Synopsis of the British Fauna 55. 271 pp.

Jägerskiöld LA. 1971. A survey of the marine benthonic macrofauna along the Swedish west coast 1921-1938. Acta regia societatis scientiarum et litterarum Gothoburgensis. Zoologia 6. $146 \mathrm{pp}$.

Johannessen T, Dahl E, Falkenhaug T, Naustvoll LJ. 2012. Concurrent recruitment failure in gadoids and changes in the plankton community along the Norwegian Skagerrak coast after 2002. ICES Journal of Marine Science 69: 795-801. doi: 10.1093/icesjms/fsr194

Josefson AB, Blomqvist M, Hansen JLS, Rosenberg R, Rygg B. 2009. Assessment of marine benthic quality change in gradients of disturbance: comparison of different Scandinavian multi-metric indices. Marine Pollution Bulletin 58: 1263-1277. doi:10.1016/j.marpolbul.2009.05.008

Karlson B, Håkansson B, Sjöberg B. (eds) 2001. The Skagerrak environmental state and monitoring prospects. Reports Forum Skagerrak, EU interreg IIC. Göteborg. 117 pp.

Karlsson A, Berggren M, Lundin K, Sundin R. 2014. Svenska artprojektets marina inventering - slutrapport. ArtDatabanken Report 16. ArtDatabanken, SLU. Uppsala. 47 pp.

Kiær H, Wollebæk A. 1913. Om dyrelivet i Kristianiafjorden. I. Lophohelia-faunaen. Nyt Magasin for Naturvidenskaberne 51: 43-52.

Loshamn AA. 1981. Descriptions of five polynoid species (Polychaeta) from the coasts of Norway and Sweden, including three new species, one new genus and one new generic name. Zoologica Scripta 10: 5-13.

Madsen FJ, Hansen B. 1994. Echinodermata Holothuroidea. Marine Invertebrates of Scandinavia 9: 1-141.

Millar RH. 1966. Tunicata Ascidiacea. Marine Invertebrates of Scandinavia 1: 1-123.

Mortensen T. 1925. An apparatus for catching the microfauna of the sea-bottom. Videnskabelige meddelelser Dansk 
naturhistorisk forening København 80: 445-451.

Müller OF. 1777-1806. Zoologiae Danica seu Animalium Daniae et Norvegiae rariorum ac minus notorum. Descriptiones et historia. Volumes I-IV. Hauniae et Lipsiae (Copenhagen and Leipzig).

Nilsson-Cantell CA. 1978. Cirripedia Thoracica and Acrothoracica. Marine invertebrates of Scandinavia 5: 1-133.

Norderhaug KM, Gundersen H, Pedersen A, Moy F, Green N, Walday MG, Gitmark JK, Ledang AB, Bjerkeng B, Hjermann DØ, Trannum HC. 2015. Effects of climate and eutrophication on the diversity of hard bottom communities on the Skagerrak coast 1990-2010. Marine Ecology Progress Series 530: 29-46. doi:10.3354/meps11306

Ørsted AS. 1845. Fortegnelse over dyr, samlede i Christianiafjord ved Drøbak fra 21-24 juli 1844. Naturhistorisk Tidsskrift, 2. rekke, vol 1: 400-427, 1 pl.

Oug E, Bakken T, Kongsrud JA. 2014. Original specimens and type localities of early described polychaete species (Annelida) from Norway, with particular attention to species described by O.F. Müller and M. Sars. Memoirs of Museum Victoria 71: 217-236.

Petersen, CGJ. 1915. Om Havbundens Dyresamfund i Skagerak, Kristianiafjord og de danske Farvande. Beretning Ministeriet for Landbrug og Fiskeri; danske biologiske station 23: 5-26.

Pethon P. 1970. Isopoda from Oslofjorden and the south coast of Norway. Rhizocrinus 1(6): 1-14.

Pleijel F. 1993. Polychaeta Phyllodocidae. Marine Invertebrates of Scandinavia 8: 1-158.

Røed LP, Albretsen J. 2007. The impact of freshwater discharges on the ocean circulation in the Skagerrak/northern North Sea area - Part I: model validation. Ocean Dynamics 57: 269-285.

Rosenberg R, Gray JS, Josefson AB, Pearson TH. 1987. Petersen's benthic stations revisited. II. Is the Oslofjord and eastern Skagerrak enriched? Journal of Experimental Marine Biology and Ecology 105: 219-251.

Salvini-Plawen LV. 1975. Caudofoveata. Marine Invertebrates of Scandinavia 4: 1-55.

Sandberg L, McLaughlin PA. 1997. Crustacea Decapoda Paguridea. Marine Invertebrates of Scandinavia 10: 1-115.

Sars M. 1868. Bidrag til Kundskaben om Christianiafjordens Fauna. Nyt Magazin for Naturvidenskaberne 15: 241-344.

Sneli JA. 1975. Mollusca Prosobranchia Forgjellesnegler nordiske marine arter. Universitetsforlaget, Trondheim. 55 pp.

Sneli JA. 2010. Norsk biodiversitetsforskning - en historikk. Naturen 2010(5): 266-280.

Sømme JD. 1927. Faunistische und Quantitative Studien über Polychaeten aus dem Lenefjord und dem Grönsfjord (südliche Norwegen). Meddelelse fra Zoologisk Musæum Oslo 11: 103115.

Soot-Ryen T, Brattström H, Sivertsen E. 1966. Marine invertebrates of Scandinavia (editorial comments). In: Millar RH, Tunicata Ascidiacea. Marine Invertebrates of Scandinavia 1. 1 p.

Ståhl H, Tengberg A, Brunnegård J, Bjørnbom E, Forbes TL, Josefson AB, Kaberi HG, Hassellöv IMK, Olsgard F, Roos P, Hall POJ. 2004. Factors influencing organic carbon recycling and burial in Skagerrak sediments. Journal of Marine Research 62: 867-907.

Winsnes IM. 1981. A new species of Lumbrineris (Polychaeta) and a new subspecies of Lumbrineris scopa Fauchald from the coast of Norway. Zoologica Scripta 10: 91-94.

Editorial responsibility: Anne Helene Tandberg.

This article is open-access and distributed under the terms of the Creative Commons Attribution 4.0 International license. This permits all non-commercial use, distribution, and reproduction in any medium, provided the original work is properly cited. (http://creativecommons.org/licenses/by/4.0/). 